\title{
Optimaalisesti rehua ja maitoa
}

\author{
Aino Wathén ${ }^{1)}$, Marketta Rinne ${ }^{2)}$ ja Anna-Maija Heikkilä ${ }^{3)}$ \\ ${ }^{1)}$ MTT Taloustutkimus, Luutnantintie 13,00410 Helsinki,aino.wathen@helsinki.fi \\ ${ }^{2)}$ MTT Kotieläintuotannon tutkimus, 31600 Jokioinen, marketta.rinne@mtt.fi \\ ${ }^{3)}$ MTT Taloustutkimus, Luutnantintie 13,00410 Helsinki,anna-maija.heikkila@mtt.fi
}

\section{Tiivistelmä}

Kotimaisen maidontuotannon kilpailukyvyn säilyttäminen edellyttää tuotannon sopeuttamista markkinoilla ja tukipolitiikassa tapahtuviin muutoksiin. Tämän tutkimuksen tarkoituksena oli selvittää, millaisia rehuyhdistelmiä käyttämällä maidontuotannon lehmäkohtainen katetuotto on paras mahdollinen ja miten markkinahintojen sekä tukien muutokset vaikuttavat tähän optimiin.

Tutkimusongelman ratkaisua varten rakennettiin dynaaminen optimointimalli, jolla maksimoitiin päiväkohtaista katetuottoa kiinteille kustannuksille. Tässä yhteydessä kiinteiksi kustannuksiksi oletettiin kaikki muut kustannukset paitsi mallissa mukana olevat rehukustannukset. Mallilla kuvattiin keskimääräisen suomalaisen lehmän rehunkulutusta ja tuotantoa kolmannella lypsykaudella. Optimointimenetelmänä käytettiin verkkoteoriaan perustuvaa lyhimmän polun menetelmää.

Käytetyt väkirehut olivat rehuvilja (ohra ja kaura 1:1) ja rypsirouhe. Lisäksi mallissa oli mukana kaksi säilörehua kerrallaan; yhteensä tutkittiin viittä erilaatuista säilörehua. Maito-, valkuais- ja rasvatuotosfunktioina käytettiin koelypsymallin pohjalta muotoiltuja yhtälöitä. Rehuannoksen väkirehupitoisuuden ja väkirehun raakavalkuaispitoisuuden vaikutukset tuotokseen määritettiin ns. Tuotosvastehankkeen tulosten pohjalta.

Perusoletusten mukaisilla rehujen ja maidon komponenttien hintasuhteilla optimiratkaisussa käytettiin tarjolla olleista halvempaa säilörehua (D-arvo 60-62). Rypsirouheen käyttö oli runsasta, koska sen antama valkuaistuotosvaste on erittäin hyvä. Korkea valkuaispitoisuus nosti maidon hintaa, joten valkuaisrehua kannatti käyttää suhteellisen paljon.

Maidon komponenttien hintasuhteiden muutoksen vaikutukset optimiin olivat vähäiset, sillä maidon koostumuksen muuttaminen ruokinnan avulla on kallista.

Viljan hinnan vaihdellessa välillä 15,0-18,3 snt/kg viljaa käytettiin sitä vähemmän, mitä korkeampi hinta oli. Vastaavasti rypsirouheen käyttö lisääntyi viljan hinnan noustessa. Molempien väkirehujen hintojen noustessa voimakkaasti maitotuotos pieneni. Samalla maidon rasvapitoisuus nousi selvästi. Kun väkirehujen hinnat nousivat $70 \%$, täytettiin mahdollisimman suuri osa lehmän energian ja valkuaisen tarpeesta kalliimman säilörehun (D-arvo $69 \%$ ) avulla.

Mallin antamien tulosten perusteella säilörehun korkean D-arvon tavoittelulle ei löydetty taloudellisia perusteita, elleivät väkirehujen hinnat nouse huomattavasti säilörehujen hintojen säilyessä ennallaan. Sekä viljaa että valkuaisrehua kannattaisi käyttää ruokinnassa nykyistä enemmän. Lehmä ei välttämättä käytännössä kykene syömään mallin valitsemia huomattavan suuria rypsirouhemääriä. Optimointimenetelmän kehittämistä voidaan jatkaa edelleen lisäämällä malliin muun muassa uusia syöntirajoitteita.

Asiasanat: lehmät, ruokinta, rehut, optimointi, katetuotto 


\section{Johdanto}

Kotimaisen maidontuotannon kilpailukyvyn säilyttäminen edellyttää viljelijöiltä tuotannon sopeuttamista markkinoilla ja tukipolitiikassa tapahtuviin muutoksiin. Tukien sekä panosten ja tuotosten hintojen muuttuessa erityisesti rehukustannusta ja sillä saavutettavaa maitotuottoa on tarkasteltava entistä kriittisemmin, sillä rehukustannus muodostaa yli $50 \%$ maidontuotannon muuttuvista kustannuksista (Enroth 2006).

Lypsylehmien ruokinnassa voidaan käyttää erilaatuisia ja -hintaisia karkea- ja väkirehuja. Tiettyyn rajaan asti rehut ovat toisiaan korvaavia. Ruokinta vaikuttaa sekä tuotosmäärään että maidon koostumukseen. Tilan taloudellinen tulos riippuu näistä molemmista, sillä rasva- ja valkuaispitoisuus määräävät maidon litrakohtaisen tuottajahinnan.

Tutkimuksen tarkoituksena oli selvittää, millaisella rehuyhdistelmällä ja tuotoksella maidontuotannon taloudellinen tulos on paras mahdollinen. Tämä tehtiin maksimoimalla kiinteille kustannuksille saatavaa katetuottoa siten, että optimoitiin rehujen käyttö päiväkohtaisesti lypsykauden aikana. Kiinteiksi kustannuksiksi tässä yhteydessä oletettiin kaikki muut kustannukset paitsi mallissa mukana olevien rehujen käytöstä aiheutuvat kustannukset. Lisäksi tutkimuksessa oli tavoitteena selvittää, miten mahdolliset muutokset tuotoksen tai panosten hinnoissa vaikuttavat ruokinnassa käytettävien rehuyhdistelmien valintaan ja sitä kautta maidon määrään ja koostumukseen.

\section{Aineisto ja menetelmät}

Tutkimusaineistona käytettiin MTT:n, Valio Oy:n, Kemira GrowHow Oyj:n ja ProAgria Maaseutukeskusten liiton yhteisen ns. Tuotosvastehankkeen (Tuotosvasteiden ja ruokinnan taloudellisuuden mallintaminen koeaineistojen perusteella; MMM Dnro 5236 / 502 / 2003). Tarkastelussa oli mukana kaikkiaan 206 vuosina 1976-2004 toteutettua koti- ja ulkomaista ruokintakoetta. Ruokintakokeiden tuloksia yhdistelemällä määritettiin, millainen tuotosvaste eri rehujen käytöllä saavutetaan. Tuotosvasteet eivät juuri riipu tuotostasosta, joten tutkimuksen tulokset ovat hyvin yleistettävissä eritasoisten lehmien ja karjojen ruokintaa suunniteltaessa (Rinne ja Huhtanen 2006).

Tässä tutkimuksessa otettiin huomioon rehuannoksen väkirehupitoisuuden ja väkirehun raakavalkuaispitoisuuden tuotosvasteet. Väkirehuvaste pienenee rehuannoksen väkirehupitoisuuden kasvaessa, koska rehuannoksen sulavuus laskee. Tällöin lehmä saa lisärehun energiasta käyttöönsä yhä vähenevän osuuden. Väkirehun raakavalkuaispitoisuuden vaste on lineaarinen. Raakavalkuaispitoisuuden nousu lisää syöntiä ja sitä kautta myös eri ravintoaineiden saantia ja tuotosta (Rinne ja Huhtanen 2006).

Käytössä ollut aineisto on ainutlaatuisen laaja. Tuotosvasteaineistosta saadut biologiset tiedot ruokinnan vaikutuksesta maidontuotantoon mahdollistivat taloudellisen optimoinnin, kun sekä rehuihin että niiden avulla aikaansaatuihin tuotoksiin yhdistettiin hinnat.

Mallissa oli mukana samanaikaisesti neljä rehua: kaksi säilörehua, rehuvilja ja valkuaisrehu. Rehuviljana oli kaikissa skenaarioissa ohran ja kauran seos (1:1) ja valkuaisrehuna rypsirouhe. Säilörehun hinnat määritettiin Enrothin (2006) ja Kuoppalan ym. (2007) tietoja yhdistelemällä. Rehuohran ja -kauran hinnat otettiin Maaseudun Tulevaisuuden (17.9.2007) julkaisemista hintatilastoista. Rypsirouheen hinta perustui kauppiaiden antamiin hintatietoihin.

Käytetyt maito-, valkuais- ja rasvatuotosfunktiot on muotoiltu suomalaiseen koelypsyaineistoon perustuvan koelypsymallin pohjalta (Nousiainen ym. 2006, Lidauer ym. 2000). Tarkasteluun valittiin kolmas lypsykausi, koska kahdella ensimmäisellä lypsykaudella tuotos poikkeaa selvästi myöhemmistä. Kolmannen kauden funktioiden käyttö mahdollistaa tulosten yleistämisen myöhempiäkin kausia koskeviksi.

Tutkimusongelman ratkaisua varten rakennettiin Matlab-ohjelmalla dynaaminen optimointimalli, jonka ratkaisuun käytettiin verkkoteoriaan perustuvaa lyhimmän polun menetelmää (Swamy ja Thulasiraman 1981). Mallin avulla pyrittiin kuvaamaan mahdollisimman tarkasti keskimääräisen suomalaisen lehmän rehunkulutusta, maidontuotantoa ja näiden perusteella määräytyvää katetta. Laskentakorkoa ei käytetty, koska mallin aikahorisontti on vain vähän yli vuoden mittainen.

Tilannemuuttujana oli aika päivinä. Ajanhetkellä 1 lehmä poiki ja viimeisellä ajanhetkellä 405 lehmä oli viimeistä päivää ummessa ennen seuraavaa poikimista. Kunkin rehun käyttöä kuvattiin omalla päätösmuuttujallaan. Muuttuja oli vektori, jonka jokainen alkio kuvasi yhtä rehun määrävaihtoehtoa. Päätösmuuttujat mallissa olivat epäjatkuvia, mikä tarkoittaa, että mallin mahdollisuudet valita käytettävä rehumäärä rajattiin ennalta määrättyihin pisteisiin. 
Säilörehun käytön optimointi erosi väkirehumäärän optimoinnista, koska tuotosvasteaineiston käyttö edellytti vapaata säilörehuruokintaa. Säilörehun osalta mallin avulla laskettiin, kuinka paljon lehmä pystyi syömään sitä rehuyhdistelmästä riippuen. Mallin sisältämistä säilörehun määrävaihtoehdoista valittiin syöntimäärän ylittävä vaihtoehto, vaikka eläimen ravintoainetarve olisi kyetty täyttämään pienemmälläkin säilörehumäärällä.

Päätösmuuttujat muodostivat neliulotteisen matriisin. Matriisin jokainen alkio sisälsi jokaisen rehuvektorin yhden alkion. Kaikki rehuyhdistelmät eivät olleet mahdollisia kaikilla ajanhetkillä eli päätösmuuttuja-avaruus riippui tilannemuuttujan arvosta. Päätösmuuttuja-avaruuden rajaamiseen käytettiin rajoitteita. Niiden avulla valittiin ne päätösmuuttuja-avaruuden alkiot, jotka saattoivat kuulua optimiratkaisuun tietyssä päätöksentekotilanteessa.

Mallin ruokintarajoitteina olivat rehuyhdistelmästä saatava energiamäärä ja OIV:n määrä, väkirehupitoisuuden yläraja ja PVT:n alaraja. Ruokintarajoitteiden lisäksi mukana oli myös säilörehun syöntirajoite. Alkiot, jotka toteuttivat kaikki rajoitteet, saattoivat tulla kysymykseen optimaalista rehuyhdistelmää valittaessa. Mallin kaikki viisi rajoitetta toimivat samalla tavalla. Jos rehuyhdistelmä rikkoi rajoitteen, se sai arvon 1, muuten rajoitteen arvo oli 0.

Maksimoitava kohdefunktio oli päiväkohtaisten tuottojen ja kustannusten erotus, josta vähennettiin rajoitteiden summa hyvin suurella luvulla kerrottuna. Jos rehuyhdistelmä rikkoi yhden tai useamman rajoitteen, tuli kohdefunktion arvosta voimakkaasti negatiivinen. Tällöin rajoitteen rikkova ruokintavaihtoehto ei tullut valituksi katetuoton maksimoivaa ruokintaa etsittäessä.

Kun kaikki tieto panoksista, tuotoksista, tuotoista ja kustannuksista oli yhdistetty yhdeksi tilanne- ja päätösmuuttujista riippuvaksi kohdefunktioksi, malli ratkaistiin. Ratkaisua varten ongelma esitettiin verkkona. Verkon solmut muodostuivat katetuottofunktion arvoista. Jotta ratkaisussa voitiin käyttää lyhimmän polun menetelmää, käännettiin katetuoton maksimointiongelma minimointiongelmaksi.

Muodostettava verkko painotettiin siten, että kullekin solmulle annettiin hyvin suuren luvun ja katetuoton erotuksen mukainen paino. Verkko suunnattiin, sillä edellisen päivän ruokintavaihtoehtoja kuvaavista solmuista voitiin siirtyä vain seuraavan päivän ruokintavaihtoehtoja kuvaaviin solmuihin. Solmuja yhdistävät kaaret osoittivat, miten edellisen päivän rehuyhdistelmää voitiin muuttaa seuraavaan päivään siirryttäessä. Verkon rakenteen avulla otettiin huomioon systeemin dynaamisuus.

Käytännössä siirtymät peräkkäisten päivien rehuyhdistelmien välillä määriteltiin tilasiirtymien avulla. Tilasiirtymämatriisi kertoi, miten verkko rakentui eli miten solmut yhdistyivät verkoksi. Märehtijän ruuansulatusfysiologian määrittelemät rajoitukset nopeille ruokinnan muutoksille otettiin huomioon siten, että edellisenä päivänä valitusta rehuyhdistelmästä voitiin siirtyä vain niihin seuraavan päivän rehuyhdistelmiin, joissa yhden tai useamman rehun käyttömäärä muuttui korkeintaan yhden, rehusta riippuvan suuruisen askeleen pienemmäksi tai suuremmaksi.

Jokaisena käsiteltävän lypsykauden päivänä voitiin valitusta rehuyhdistelmästä siirtyä $3^{4}=81$ seuraavan päivän rehuyhdistelmään (solmuun). Rehuyhdistelmästä riippuvia solmuja yhdistäviä suunnattuja kaaria oli muodostuneessa viisiulotteisessa verkossa yli 10 miljoonaa. Lyhin reitti verkon läpi etsittiin Dijkstran algoritmin avulla. Tässä työssä käytettiin Matlab-ohjelman Matlog-toolboxin työkaluja pred2path.m ja dijk.m (Kay 2006).

Tulokseksi saatiin optimaalinen "ruokintareitti" eli listaus solmuista, joiden kautta lyhin polku verkon läpi löytyi. Ruokintastrategian lisäksi mallista saatiin kohdefunktion optimaalinen arvo eli katetuotto lypsykauden aikana ja maitotuotos. 


\section{Tulokset ja tulosten tarkastelu}

Mallin avulla tutkittiin perustilanteen lisäksi 24 erilaista skenaariota. Lähtökohtana oli keskimääräinen suomalainen lehmä C1-tukialueelta. Kaikki esitetyt tulokset ovat lehmäkohtaisia.

Taulukko 1. Tulokset mallin perusoletuksilla.

\begin{tabular}{|l|r|}
\hline rehujen kulutus & kg/lypsykausi \\
\hline säilörehu, D 69 & 240 \\
\hline säilörehu, D 60 & 16070 \\
\hline rehuvilja & 2448 \\
\hline rypsirouhe & 2172 \\
\hline väkirehun osuus & $55 \%$ \\
\hline tuotokset & kg/lypsykausi \\
\hline maito & 10575 \\
\hline valkuainen & 341 \\
\hline rasva & 391 \\
\hline kate kustannuksille & $\mathbf{f / l y p s y k a u s i ~}$ \\
\hline (pl. rehukustannukset) & 2764 \\
\hline
\end{tabular}

Taulukossa 1 on esitetty tulokset mallin perusoletuksilla. Päätösmuuttujien arvojen valinta vaikuttaa jonkin verran tuloksiin. Nämä tulokset saatiin, kun säilörehumuuttujien vaihtoehtoiset arvot olivat $0 \mathrm{~kg}$ ja $35-50 \mathrm{~kg}$ viiden $\mathrm{kg}: n$ välein ja vilja- ja rypsirouhemuuttujien arvot 0-13 kg 1-3 kg:n välein. Rehujen määrävaihtoehtoja lisäämällä optimin tarkkuus paranee, mutta laskenta-aika lisääntyy.

Optimiratkaisussa ruokinnassa käytettiin halvempaa säilörehua (D-arvo $60 \%$, hinta $1,51 \mathrm{snt} / \mathrm{kg}$ ) lypsykauden ensimmäisiä päiviä lukuun ottamatta. Perusoletusten mukaisilla rehujen ja maidon komponenttien hintasuhteilla rypsirouheen käyttö oli runsasta, koska sen antama valkuaistuotosvaste on erittäin hyvä. Korkea valkuaispitoisuus nosti maidon hintaa, joten valkuaisrehua kannatti käyttää suhteellisen paljon.

Tukialueita vertailtaessa otettiin huomioon sekä säilörehun tuotantokustannusten kautta määritettyyn hintaan vaikuttava pinta-alaperusteinen tuki että maidon litraperusteinen tuotantotuki. Eteläisimmillä alueilla peltoviljelyn tuet ovat korkeammat kuin C-alueella, mutta A- ja B-alueilla maidontuotantotuki on matalampi. Säilörehun sadon ja tuotantokustannusten oletettiin olevan samansuuruiset eri tukialueilla. Ruokintastrategia A- ja B-alueilla oli sama eikä eronnut kovin paljoa C-alueiden optimaalisesta rehujen käytöstä. Korkeampi tuotantotuki C-alueilla kannusti tuottamaan hieman enemmän maitoa, mutta ero vuositasolla jäi vain 29 litraan. Tämä tuotoslisä saatiin vähentämällä hieman viljan ja lisäämällä rypsirouheen käyttöä.

Valkuais- ja rasvakymmenyksen hintoina käytettiin Valion tuottajahintoja alkuvuodesta 2007. Lähtökohtana on 3,3\% valkuaista ja 4,3 \% rasvaa sisältävä maito, jolloin maidon hinnasta noin $2 / 3$ määräytyy valkuaispitoisuuden perusteella ja 1/3 rasvapitoisuuden perusteella. Valkuaisen hintaa nostettiin 5-25\% ja samalla rasvan hintaa laskettiin siten, että 3,3\% valkuaista ja 4,3\% rasvaa sisältävän maidon litrahinta säilyi ennallaan. Hintasuhteen muutoksen vaikutukset ruokintaan, tuotokseen ja tuottoon olivat vähäiset.

Rehuviljan hinta laskettiin ohran ja kauran hintojen keskiarvona. Viljan hinnan vaihdellessa välillä 15,0-18,3 snt/kg viljaa käytettiin sitä vähemmän, mitä korkeampi hinta oli. Vastaavasti rypsirouheen käyttö lisääntyi viljan hinnan noustessa. Kovin suuria pelkän viljan hinnan muutoksia ei katsottu olevan tarpeen tutkia, koska myös rypsirouheen hinnan oletettiin nousevan viljan hinnan noustessa.

Molempien väkirehujen hintojen noustessa voimakkaasti (10-70\%) tuotto väheni selvästi. Lisäksi maitotuotos pieneni. Maidon rasvapitoisuus nousi selvästi. Kun väkirehujen hinnat nousivat $70 \%$, täytettiin mahdollisimman suuri osa lehmän energian ja valkuaisen tarpeesta kalliimman säilörehun avulla. Väkirehutäydennystä käytettiin siksi, että eläimen rajallinen säilörehun syöntikyky esti pelkän säilörehun käytön. 
Erilaatuisten säilörehujen käytön vaikutusta tutkittiin C1-tukialueen tuotantokustannusja -tukitiedoilla. Taulukossa 2 on listattu säilörehun laadun vaikutukset eri rehujen kulutukseen ja niiden antamiin tuotoksiin.

Taulukko 2. Säilörehun laadun vaikutus rehujen kulutukseen, tuotokseen ja tuottoon.

\begin{tabular}{|l|l|r|r|r|r|}
\hline D-arvo ja sato & säilörehu 1 & 69,1 sato & 69,1 . sato & 69,1 . sato & 63,1 . sato \\
\cline { 2 - 6 } & säilörehu 2 & 60,1 sato & 65,2 . sato & 62,2 . sato & 62,2 . sato \\
\hline $\begin{array}{l}\text { rehujen kulutus, } \\
\text { kg/lypsykausi }\end{array}$ & säilörehu 1 & 240 & 130 & 90 & 380 \\
\cline { 2 - 6 } & säilörehu 2 & 16070 & 18210 & 18245 & 17955 \\
\cline { 2 - 6 } & rehuvilja & 2448 & 2187 & 2522 & 2068 \\
\cline { 2 - 6 } & rypsirouhe & 2172 & 1959 & 1916 & 2543 \\
\hline \multirow{2}{*}{$\begin{array}{l}\text { tuotokset, } \\
\text { kg/lypsykausi }\end{array}$} & maito & 10575 & 10291 & 10338 & 10529 \\
\cline { 2 - 7 } & valkuainen & 341 & 338 & 339 & 340 \\
\cline { 2 - 7 } & rasva & 391 & 400 & 399 & 395 \\
\hline tuotto, f/lypsykausi & & 2764 & 2698 & 2726 & 2661 \\
\hline
\end{tabular}

Maatiloilla syötettävien säilörehujen valikoima ei käytännössä ole kovin monipuolinen, mutta se vaihtelee vuosittain. Tutkituista vaihtoehdoista parhaaseen taloudelliseen tulokseen päästiin, kun käytettiin säilörehua, jonka D-arvo on matala, 60-62. Korkeamman D-arvon säilörehua käytetään vain aivan lypsykauden alussa.

\section{Johtopäätökset}

Perusoletuksilla mallin antamat tulokset poikkeavat jonkin verran nykyisestä ruokintakäytännöstä. Karkearehun käyttö on vain hieman suurempaa kuin karjantarkkailuaineistosta laskettuna, mutta väkirehun määrä ruokinnassa on yli 1000 rehuyksikköä suurempi vuodessa. Tämä, samoin kuin mallin antama korkeampi maitotuotos, selittyy osittain sillä, että tutkimuksen kohteena oli kolmas lypsykausi. Tarkkailuaineistossa sen sijaan ovat mukana myös kaksi ensimmäistä, matalamman tuotoksen lypsykautta.

Mallin antamien tulosten perusteella sekä viljaa että valkuaisrehua kannattaisi käyttää ruokinnassa selvästi nykyistä enemmän, sen sijaan säilörehua voisi käyttää hieman vähemmänkin. Korkean D-arvon tavoittelulle ei löydetty perusteita, elleivät väkirehujen hinnat nouse huomattavasti säilörehujen hintojen säilyessä ennallaan. Jos väkirehujen hinnat nousevat yli $50 \%$ nykyisestä säilörehun tuotantokustannusten säilyessä ennallaan, kannattaa viljelijän panostaa säilörehun laatuun määrän sijasta.

Erilaatuisten säilörehujen käyttö tai maidon komponenttien hintasuhteiden muutos eivät vaikuttaneet maidon valkuaispitoisuuteen. Kaikilla tutkituilla säilörehuilla ja hintasuhteilla maidon valkuaispitoisuudeksi saatiin 3,2-3,3\%, eikä siihen voitu ruokinnan avulla juurikaan vaikuttaa. Korkein valkuaispitoisuus saatiin, kun väkirehujen hintoja nostettiin voimakkaasti. Tämäkin muutos johtui lähinnä siitä, että vähäisemmän väkirehuruokinnan takia tuotettu maitomäärä pieneni.

Valkuaisrehun runsas käyttö ruokinnassa on ristiriidassa nykyisen käytännön kanssa. Mallin valitsemat rypsirouheen käyttömäärät ovat niin suuria, ettei lehmä välttämättä kykene käytännössä syömään niin paljoa. Tämä työ onkin ensisijaisesti nähtävä menetelmän kehitystyönä. Malliin voidaan myöhemmin lisätä rajoitteita, mikäli tuloksia käytäntöön sovellettaessa mallissa havaitaan puutteita.

Tärkein jatkotutkimuskohde on mallin tekninen kehittäminen. Jotta mallin antamia tuloksia voitaisiin hyödyntää esimerkiksi neuvonnassa, olisi sen toiminnan oltava nopeampaa kuin tällä hetkellä ja parametrien muuttaminen tulisi olla yksinkertaisempaa. Lisäksi olisi hyödyllistä sisällyttää malliin kolmannen lypsykauden lisäksi ensimmäinen ja toinen lypsykausi. Ensimmäisten lypsykausien lisääminen antaa mahdollisuuden selvittää lypsykausien vaikutusta toisiinsa.

Tällä hetkellä mallin avulla voidaan optimoida perinnöllisiltä ominaisuuksiltaan keskimääräisen lehmän ruokintaa ja tuotantoa. Käytännössä tuotosominaisuuksissa on suuria yksilöiden välisiä eroja, joiden huomioonottaminen laajentaisi mallin käyttömahdollisuuksia huomattavasti. 


\section{Kirjallisuus}

Enroth, A. (toim.) 2006. Mallilaskelmia maataloudesta 2006. ProAgria maaseutukeskusten liiton julkaisuja 1020.48 s. ISBN 951-808-142-5.

Kay, M. G. 2006. Matlog Version 9. Saatavilla: http://www.ise.ncsu.edu/kay/matlog/. Viitattu 11.6.2007.

Kuoppala, K., Rinne, M., Nousiainen, J. \& Huhtanen, P. 2007. The effect of cutting time of grass silage in primary growth and regrowth and the interactions between silage quality and concentrate level on milk production of dairy cows. Livestock Science. In press.

Lidauer, M., Mäntysaari, E. A., Strandén, I. \& Pösö, J. 2000. Multiple-trait random regression model for all lactations. INTERBULL Bulletin No. 25:81-86.

Nousiainen, J., Jauhiainen, L. \& Huhtanen, P. 2006. Lypsylehmien kestävyyden vaikutukset maidontuotantoon ja rehun hyväksikäyttöön. . Julkaisussa: Maataloustieteen päivät 2006 [verkkojulkaisu]. Suomen maataloustieteellisen seuran julkaisuja no 21. Toim. Anneli Hopponen. Julkaistu 9.1.2006. Saatavilla: http://www.agronet.fi/maataloustieteellinenseura/. Viitattu 11.9.2007. ISBN 951-9041-49-4.

Rinne, M. \& Huhtanen, P. 2006. Paljonko maitoa saa tonnista rehuviljaa? Esitelmä ProAgria Maito -valmennuspäivillä 24.8.2006. Saatavilla:

https://portal.mtt.fi/portal/page/portal/Artturi/Artturikirjasto/Artturikoulutus/ProAgria\%20Maito\%20valmennus\%20200 6\%20-\%20Koulutusmateriaali/Marketta\%20Rinne\%202006.pdf. Viitattu 4.9.2007.

Swamy, M. N. S. \& Thulasiraman, K. 1981. Graphs, Networks, and Algorithms. 592 p. New York. 